\title{
Identifying the Immediate and Remote Causes of Pipeline Disasters in Nigeria
}

\author{
By Francis I. Johnson \& Marianthi Leon
}

Robert Gordon University

Abstract- Several occurrences of the transport system of the natural gold vandalisms in Nigeria, especially in the Niger Delta part of Nigeria is so upfront and seem neverending. However, this seemed also to be a result of many factors ranging from the unemployment of youths and the inadequate management and necessary government policies to be put in place to ensure guaranteed security. Past researchers have observed and given the fact that the major causes of this disaster are attached to a technical fault and some failures in aging, corrosion, and mechanical challenges like those welding effects. This research work examined immediate and remote causes of pipeline disasters considering the dimension of factors, the level of preparedness of people for the pipeline disasters, and the risk perception of people, the socioeconomic characteristics and the destruction of the pipelines.

Keywords: oil spill, oil theft, pipeline attacks vandalism interdiction, GIS, environmental impact mitigation, data, nigeria.

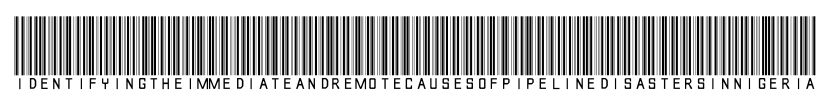

Strictly as per the compliance and regulations of:

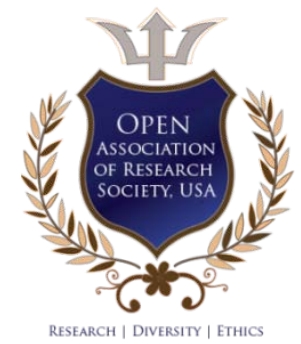

(C) 2020. Francis I. Johnson \& Marianthi Leon. This is a research/review paper, distributed under the terms of the Creative Commons Attribution-Noncommercial 3.0 Unported License http://creativecommons.org/licenses/by-nc/3.0/), permitting all non commercial use, distribution, and reproduction in any medium, provided the original work is properly cited. 


\title{
Identifying the Immediate and Remote Causes of Pipeline Disasters in Nigeria
}

\author{
Francis I. Johnson ${ }^{\alpha}$ \& Marianthi Leon ${ }^{\sigma}$
}

Abstract-Several occurrences of the transport system of the natural gold vandalisms in Nigeria, especially in the Niger Delta part of Nigeria is so upfront and seem neverending. However, this seemed also to be a result of many factors ranging from the unemployment of youths and the inadequate management and necessary government policies to be put in place to ensure guaranteed security. Past researchers have observed and given the fact that the major causes of this disaster are attached to a technical fault and some failures in aging, corrosion, and mechanical challenges like those welding effects. This research work examined immediate and remote causes of pipeline disasters considering the dimension of factors, the level of preparedness of people for the pipeline disasters, and the risk perception of people, the socioeconomic characteristics and the destruction of the pipelines. This study posted the analytically with the use of confirmatory factor analysis (CFA) and descriptive statistics. This analytical tool is regarded as a superior model of analysis because its purpose is to establish a figurable relationship between observed and unobserved variables. The study involved 300 respondents out of which 286 is regarded valid, which is way above $90 \%$ of the respondents who were selected within Nigeria using the multisampling method, and the method is the simple random method. The results from the study show the existence of a significant factor such as poverty, poor management of pipelines, political factors and all other factors treated in the study contribute to the pipeline disaster in Nigeria. Further, it was also observed that preparedness and risk perceptive factors also contribute to pipeline disaster in Nigeria. After all views and detailed explanations put to test by the respondents and researchers respectively; the result suggests that there should be a provision of employment for citizens, especially the active youths that could lead such vandalism. Also, it recommends that there should be a provision of social amenities and infrastructural facilities such as roads, electricity, pipe-borne water, and reduction in land devastation so as to reduce violence.

Keywords: oil spill, oil theft, pipeline attacks vandalism interdiction, GIS, environmental impact mitigation, data, nigeria.

\section{INTRODUCTION}

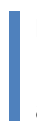
n simple terms, crude oil is a naturally occurring fuel (liquid) that is found under the ground. It is regarded as one of the natural resources which have benefited humanity alongside others like air, water, food, and many more. Crude oil can be gotten from the ground through extraction by drilling. Crude oil is referred to as

Author a $\sigma$ : School of Architecture and Built Environment, Robert Gordon University, Aberdeen, UK. e-mail: f.johnson6@rgu.ac.uk fossil fuel because of its origins. Over the years, crude oil has gained popularity mostly because of its economic impact but also because of its diversified usable products refined from it. It has gradually become the source of national development in terms of economic value and also infrastructural growth to South America, North America, Europe and the Middle East (Karl, 1997). As it is a natural resource, it's no news that most oil-producing countries have their government involvement in its management. As seen in countries like Argentina, Bohemia, Great Britain, Egypt, and even around the world. Modern strategies like the one employed by the British government such that they established a petroleum administration which owns a controlling partnership with veto powers on the board of directors in the Anglo-Persian oil company. They also control the oil resources of the greater part of Iran; offers funds to support the development of oil and as such giving rooms to promoting the acquisition of subcompanies and companies under companies exclusively British or under British control.

In Nigeria, the Niger-Delta region is highly ranked in the world And as such the first in Africa which has a landmass covering about $36,000^{2} \mathrm{~km}$ (squarekilometers) of lagoons and marshlands. The region harbors the Nation's reserves to the tune of fewer than 35 billion barrels of crude oil, which is suspended for further needs and less than 165 trillion cubic feet of natural gas (Omotola, 2009). Nigeria's major source of earning is petroleum, and most of the petroleum is found in the Delta state part of the country. Despite that the Niger-delta has access to this crude oil in abundant quantity, the state is considered as one of the states that are suffering from the activities of crude oil as a result of many factors (UNEP, 2011). Although it is significant, we note that Nigeria ranks first in Africa and eighth in the world when it comes to oil export according (Umar, 2014). So, oil production contributes about a billion investments to boost the country's economy as well as the development of related sectors such as infrastructures, provision of employment for Nigerians as well as improvement of the standard of living of the people. In an aim to develop, quite a few African countries have enabled extreme measures and jeopardized the wellbeing, both health-wise and socially, of their citizens, thereby leading to environmental hazards as a result of crude oil extraction. For example, as explained by Pepper using the Friedman's core- 
periphery model in (Friedman, 1973), the areas where petroleum resources are exploited are often categorized based on economic and environmental impoverishment caused by continuous exploitation in those oil-based areas while the development of the urban center which are usually a government administrative seat is improved upon. Although the urban areas also face challenges of environmental degradation and kinds, it tends to be tactically under control, unlike the rural areas where this extraction takes place.

There have been numerous hazards, most resulting from human negligence for wellbeing, which resulted in detrimental incidences such as from gas flaring, industrial pollution, farmland losses, oil spillage, and eventually leading to loss of lives and properties. All these effects are results of irregular exploitation of crude oil and the acts of citizens of the country bringing about vandalism of pipelines. Eze (2004) stated that Vandalization which can be define as the "illegal act of destroying or puncturing oil pipelines either to disrupt oil supply or steal crude oil - or its refined products- to appropriate for personal use or sale on the black market or any other outlet; is outlawed by the provisions of 'Production and Distribution (Anti-sabotage) Act' and the 'Criminal Justice (miscellaneous provisions) Decree of 1974". Because Pipeline vandalism and ruptures are the regular incidents that cause oil spillages, fires, and explosions in Nigeria, leading to pipeline disasters.

Also, factors contributing to these pipeline disasters, some of which are majorly technical failures such as inadequate maintenance and regular inspection, operational failures, and natural disasters are some factors causing pipeline disasters. It poses as one of the problems associated with pipeline disasters, which are affecting the source of revenue for government and oil companies operating in Nigeria. Pipelines vandalism may be a result of a natural situations but could also be for selfish reasons to personal gain by greedy individuals through the deliberate use of explosives or machines to cut or drill pipelines. It could sometimes not be for greed for some scary interest, which is unfair to the citizens such as; Scarcity of petroleum products, protest neglect from government, and degradation of the environment as a result of oil companies' activities. Very many incidents resulting from pipeline disasters in Nigeria have summoned the attention of other countries to the consistent death, property loss, and water pollution resulting from this disaster. Not to mention the soil contamination, air pollution, destruction of the ecosystem (flora and fauna), property and infrastructures, and loss of crude oil and refined products.

\section{a) Research gap}

The study are a confirmed that there is widespread of oil pipeline and its channel towards petrol products. It makes all parts of the study area vulnerable to attack such as vandalism by Citizen for selfish gains and endangering the lives of the less concerned. Therefore, a quantitative approach which identifies the statistical significance of crude oil transport system vandalism based on the regional classification within Nigeria.

\section{b) Statement of the Problem}

As the never relenting disasters of transport systems of crude oil are increasing, so also does the limitation to the number of barrels of petroleum in Nigeria and of course, in turn, affects the revenue generation for the country and oil companies. Also, it does also have effects on the socioeconomic characteristics of the victims in such areas and on the farmlands, thereby also endangering food security. Although efforts are been put to place to identify other possible causes of pipeline disasters it rings round the possibility of vandalism and irregular maintenance of petroleum production.

c) Research Questions

(i) What Is the Dimension of the Factors that Causes Pipeline Disaster in Nigeria?

(ii) What is the Level of Prepardness for Pipeline Diaster?

(iii) What is the Risk Perception of Respondents on Pipeline Disaster?

(iv) What is the Impact of Risk Perception of People, Preparedness a and Demographic Factors on Pipeline Disaster in Nigeria?

d) Research Objectives

The Broad Objective of this Study is to Determine the Immediate and Remote Cause of Pipeline Disaster in Nigeria.

The specific objectives taking a case study of 20 years; from year 2000 to 2019 , are to:

(i) Determine the !dimension of the factors that causes Pipeline Disaster in Nigeria.

(ii) Examine the level of Preparedness of people on pipeline disaster in Nigeria using Confirmatory Factor. Analysis (CFA).

(iii) Determine the risk Perception of Respondents on Pipeline disaster.

(iv) Examine the impact of risk perception of people, preparedness and demographic factors on pipeline disaster in Nigeria using Confirmatory Factor Analysis (CFA).

e) Hypothesis of the study form, thus:

The hypothesis for the study is stated in the null

Ho: There is no significant effect of socio-economic characteristics of the respondents and the pipeline vandalism. 


\section{f) Significance of the Study}

The revenues from oil, of course, presented accumulated level of wealth, giving room for investing more and planning for other sectors based on income generated from crude oil. However, the source of this revenue is invariably becoming the main source of income for the country, and the macro-economic management begins to rely more on the report and result of crude oil sales as a determinant of the state of the economy. Even though crude oil seems to contribute more to the country's national economic development, the problems of the economy are still not limiting or mitigating. Such problems has an unemployment rate, manufacturing decline rate, increasing poverty level, and poor infrastructural development. The dismal performance of the Nigerian economy in the face of huge rents from oil and high income that is still not limiting the problems of the country has shown that the importance of oil to the country s economic development is questionable. It is also from the obvious that as a result of personal gain seekers, the whole of crude oil becomes an endangering source leading to loss of valuables, including lives. The above therefore indicates that the advantages offer as tremendous effect to get on just like that of the disadvantage also cause for attention.

\section{il. Empirical Literature RevieW}

\section{a) History of Crude Oil in Nigeria}

Although it may seem like Nigeria came into their oil and gas bloom overnight, the fact is, oil discovery in Nigeria stands as far back as 1903 with the Nigerian Bitumen Corporation. They had just started conducting an exploratory project when the attack of world war I began, and as such, all operations of the firm had to be on hold. After that, some other small oil companies tried to pick up the slack but were handicapped by limited facilities as there were not many funds to acquire the needed technology until the many oil-producing sectors commenced with another company that came into the scene and took over the exploration of commercial crude oil in Nigeria.

In 1923, exploration licenses were awarded to D'Arcy Exploration Company and Whitehall Petroleum,still, the two companies did not see reasons to believe that oil has a value in the market as a result of the record sales and potential gains in view. In 1937, after another license was issued to the Shell D'Arcy petroleum development company of Nigeria, a consortium of Shell and British Petroleum, they began their explorations all over the country. In 1953, Oil was discovered in Akata, Afam, and Bomu in Ogoni territory but all in non-commercial quantities till 1956, when oil of commercial quantity was discovered in Oloibiri, Niger Delta area of Nigeria. So, the commercial oil filed began production in 1958. Other non-British companies like Mobil, Gulf Oil, Chevron, and Elf were also issued licenses to explore oil in the 1950s. Although this marked a decline in the production of agricultural export crops (which used to be the pillar of the economy), the economy of Nigeria experienced a boost with this discovery. After 1960, exploration rights were extended to other foreign companies to explore oil in both theinshore and offshore areas of the Delta state.

The discovery of oil in Nigeria placed Nigeria in rank with other oil producers countries when its first oil field started producing commercial quantities of about 5,100 BPD. The first EA filed was discovered by Shell in shallow water southeast of Warri. The end of the Biafran war in 1970 coincided with the rise in the world oil price, and Nigeria was able to accumulate noncapital demanding riches that are spontaneous from the production of oil. During the period of the late 1960s to early 1970s, Nigeria was able to level up to the production of fewer than 3 million barrels of crude oil daily.

It is worthwhile to also know that the Nigerian Government officials have been the ones accessing the profits derived from oil exploration. In 1971, as a result of the level of crude oil available for Nigeria and its potential export rate. Nigeria because she discovered crude oil and relevance to oil matters made rejoined the organization of Petroleum Exporting Countries (OPEC) and simultaneously needs to set up her own petroleum company which led to the establishment of the Nigerian National Petroleum Company (NNPC) in 1977, which is state-owned and controlled company which was to play a key role in both streaming sectors. Strategies were then put in place to increase the production of 4 million barrels per day by the year 2010 .

The production of crude oil and its export has played a vital role in national development and so accounts for about almost $100 \%$ of her total revenue. In the last two decades, oil and gas exports accounted for more than $98 \%$ of export earnings and approximately $83 \%$ of federal government revenue, as well as generating more than $14 \%$ of its GDP. It also yields $95 \%$ of foreign exchange earnings and about $65 \%$ of government budgetary revenues.

\section{b) Pipeline Network in Nigeria}

Although Nigeria has a total of 159 oil field and 1,482 oil wells in operation. According to the Department of Petroleum resources, the most productive region in terms of quantity derived is from the Niger Delta Basin in Niger Delta, which encompasses 78 of the 159 oil fields. Most of the other oil fields in Nigeria are minute and not in a single place, and as a result of this, an extensive and well-developed pipeline network was developed to transport the oil.

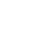

(1)




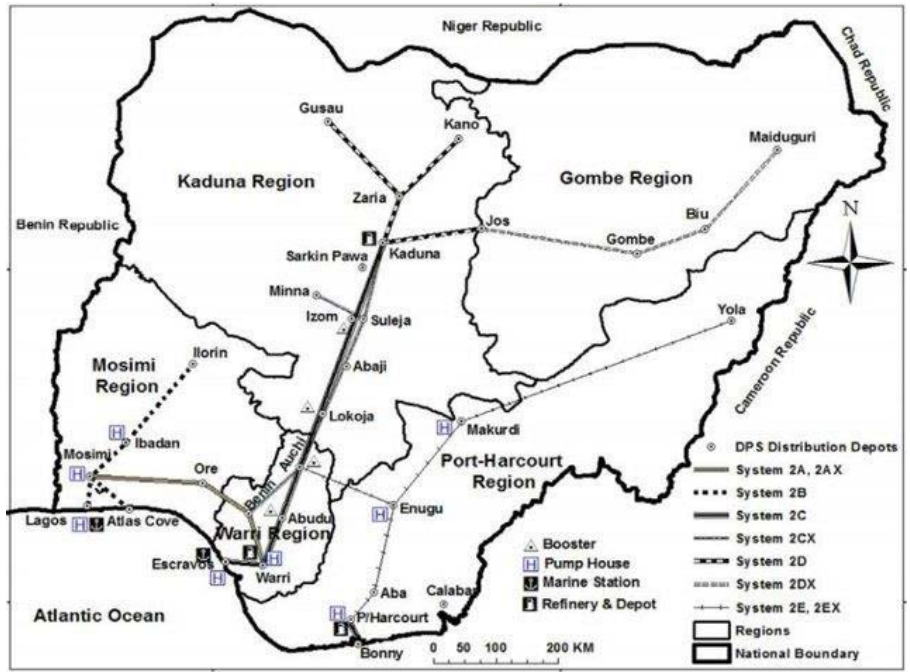

Fig. 1: Pipeline network in Nigeria

Pipelines in Nigeria (NNPC, 2019) in figure 1shows the pipeline systems used for transporting petroleum products (mainly Premium Motor Spirit (PMS), Automated Gas Oil (AGO), and House Hold Kerosene $(\mathrm{HHK}))$ in Nigeria. The pipeline system is strategically classified into five (5) operational regions. The Nigerian National Petroleum Corporation (NNPC) own and operate the $5001 \mathrm{~km}$ asset through its subsidiary, the Pipeline Petroleum Marketing Company (PPMC). The PPMC pipeline network is made up of multiproduct systems for product supply: the buried pipelines link the refineries with distribution depots.

Proper and effective pipeline Network for the transport of petroleum and other natural resources was put in place in 1979. This form of bulk transport system increased the connection to improve the country's oil production and meet its growing needs for further distribution and consumption. Today, the pipeline network extends to $3,000 \mathrm{~km}$, liking together the major refineries with nineteen depots. There are four refineries in the country: one each in Kaduna and Warri; and two in PortHarcourt, with a nameplate capacity of 438,750 billion b/d. The Kaduna refinery is also linked to the Escravos(Lagos) terminal, through Warri, by a crude oil pipeline. The pipelines are then divided into nine. Since 1979, the advent of this pipeline mode of transport has accounted for 68 percent of all refinery products transported and this number has increased over the years.

\section{c) Pipeline Disasters (PPMC, 2018)}

Disaster is any occurrence in shock which could either be naturally occur in, or otherwise, which has way impact, and severity on the individual, community or society and they must respond to this sudden or progressive effect by taking standard measures. It's no news that the familiarity of this word is a growing concern in the world today. This phenomenon of disaster is becoming rampant in society and concern throughout the world at large. The challenges associated with pipeline alone are enormous and, as such, trend more risks to the lives of people, their properties, and even making their environment unsafe to them. Also, the sources of income of the people tend to be threatened there's more risk in the level of occurrence of disasters for large populations in recent years as a result of pipeline disaster due to the volatile nature of petroleum products. The occurring disasters have led to the loss of lives and properties in Nigeria.

The Risk management board of Bovas (2018) states:

September 2017 : > 160 killed in Asaba

April 2011: > 175 killed in Lagos

July 2008: > 200 killed in Delta

Dec 2006: > 270 killed in Lagos;

May 2006: > 160 killed in Lagos;

Dec 2004: > 30 killed in Lagos;

Sept 2004: > 70 killed in Lagos;

June 2003: >125 killed in Abia;

Jul 2000: >310 killed in Warri; Mar 2000: >70 killed in Abia;

Oct 1998: >1,170 killed in Jesse.

\section{d) Immediate Causes of Pipeline Disasters}

Petroleum is a complex mixture of hydrocarbons. It is a natural occurring fossil fuel as it is an accumulation of the remain of dead organic matter such as animals and plants that decayed several years ago. These remains sank to the bottom of water bodies and passed through a lot of processes under pressure, temperature, and heat, which makes sediment and then referred to as sedimentary rocks. Although Petroleum is a general word in describing a wide range of hydrogen and carbon compounds that are either gases, liquids, or solids under the earth's surface. There are several forms of petroleum, but the common ones are natural 
gas and crude oil, which is sometimes used for the world petroleum. Petroleum consists of complex hydrogen, and carbon compounds like alkanes, alkenes and alkynes. They posses different colors and vary depending on the chemical composition, which could be red, brown, black, red, yellow, and sometimes green.

There are causes of pipeline disasters, and many are grouped into Structural problem (40\%), operational error $(6 \%)$, outside force damage $(27 \%)$, control problems (2\%) and others (25\%). In 2005, Moffat and Linden published compiled background research and information associated with oil pipeline failures. The report showed that the causes of downfall on the part of the pipeline are not accrued to a particular secto, which is why it's random. Whenever the transport system also blow up, the crude oil been transported at the moment is lost, and that brings shortage to the crude oil and the subsequent passage of petrol transport to other countries either as export or import. This will also bring about an increase in the value attached to the selling of crude oil as a result of damages caused to the transport system. (UNDP, 2006). Research studies have proved that there is more factual evidence of the relationship between the unstable oil-producing regions in Nigeria and the prices they are put for sale (Khalifa, Alsarhan, \& Bertuccelli, 2017). There's a higher level of unstable production in oil-producing regions as there will be no exact quantity expectancy of crude oil and as such causes disruption in the chain supply as stated in (Misund and Oglend 2016) and (Chen and Xiao, 2015). They also pointed out that petroleum companies usually try to find ways of controlling expected destruction in the supply chain by adopting strategies which may affect the demand and supply more effectively (Liu, Liu, Zhu, Wang, and Liang (2016).

Another important factor contributing to the pipeline vandalism in Nigeria is Institutional factors, just like it is in many other African countries. Practical results show that there's a high level of correspondence between poor governance and pipeline vandalism. Several African and Latin American Cities are faced large socioeconomic challenges, which were observed to have a ripple effect on macroeconomic instability such as high government budgets with little or no positive results, high inflation rate, and weak legal systems. Weak institutions promote macroeconomic instability, which leads to unstable property rights and also a lack of equal opportunities for education, which may lead to state failure (Acemoglu, Johnson, Robinson, \& Thaicharoen, 2003). This factor also points to the reason why many developing countries have a high level of corruption promoting weak law and the absence of accountability. This also explains the low freedom level enforced by the government on her citizens (Bräutigam \& Knack, 2004). OSHA (2017) also emphasized that some acts of the government and some stakeholders also accounts for this usual pipeline explosions, of which such attributes include; Negligence, carelessness, and violations of Occupational Safety and Health Administration, workplace safety regulations, are few among the regular factors. Another factor that causes Pipeline explosions is when carelessness of citizens in such that when heavy-duty machines like drilling borehole machines hit a pipeline, which may eventually lead to an explosion.

In Addition to all the factors causing pipeline accidents, other factors that can cause a pipeline accident include:

- Poor maintenance of pipes, joints, and valves

- Metal fatigue

- Corrosion

- Mechanical damages.

- unduly repair welds

- Faulty products

- Chemically caused accidents.

- Mis input of application codes.

- Inadequate safety practices

- Pipeline companies are often

It is no news that the institutions such as governmental agencies guiding Nigeria has failed in years back, which is leading to the counter-reaction by her citizens. UNDP (2006) also observed that even though a large amount of funds is allocated to NDDC, OMPADEC, and derivation fund to enhance the development of the region, less is achieved. This Is believed to be a result of corruption, mismanagement of funds, and abuse of constitutional rights acclaimed to citizens. The reason why there has been no meaningful development through infrastructural provision as environmental protection is not prioritized as a result of bad governance. In addition, D'Agostino et al. (2016) posted that on the note that there are abundant resources that are meant to benefit and improve the lives of Africans, which turns out to be natural resources of curse leading to conflict as a result of greediness, and corruption. It is reasoned that a country's institution in which the legal, social and political system influences the economic performance of the country could not do much to make a difference. (Ambituuni, Amezaga \& Emeseh, 2014; Kherallah \& Kirsten, 2002). Sadly, weak government institutions results in failures to protect the environment because of the poor enactment of environmental laws (Amezaga, 2015). This will not only happen but also inspires the host communities and make youths see more reasons to vandalize governmental properties, especially the pipelines with the aim of reacting to the negligence of government and destruction of their lands and water bodies.

This then turns to a channel for sustenance of life and occupation for many active abled bodies and 
even community leaders in the Niger Delta part of Nigeria. Countless researches claimed that weakness of organization bodies, both governmental and nongovernmental, injustices, and corrupt acts force people to retaliate back in a negative channel and quite self-destructive (Dzhumashev, 2014). Also, D'Agostino et al. (2016) blamed governmental bodies for ever-increasing budget without putting to priority the well being of the citizens in terms of basic amenities, which will promote corruption and encourage the citizens to strive for themselves either legally or otherwise. All these are resulting in anger and loss of confidence in government by the youths triggers the vandalism of pipelines. This evidence is spare head has the number of programs set up by the Nigerian government such as the NDDC, OMPADEC, MND, which failed to serve the proposed purpose as a result of corruption, which has inspired pipeline vandalism. Akpomera (2015) observed that policies enacted by these ruling political institutions of rationalize always support unfair act by their team circus of elites and government officials, which in turn lessen the people's trust in the government and justice system. Ulman and Bujancă (2014). Although the military option was taken to deal with authority body in the pipeline disasters of Niger delta region of Nigeria which led to the befall on the citizens even victims that has little or no idea about the vandalism and there death was recorded as many civilian death as reported by Lutz, 2013).

Nigeria exports a substantial quantity of crude oil as a revenue generation channel, and the United States is a spring day customer as they consume about $40 \%$ of Nigeria's total oil exports. Although, Nigeria only provides $10 \%$ of its imports but ranks as the fifthlargest source for the U.S. imported oil (Bovas, 2018). Nigeria has been a member of the Organization of Petroleum Exporting Countries (OPEC), in mid-2001, it's crude oil production was averaging around 2.2 million barrels $(350,000 \mathrm{mi})$ per day. Recent studies show that Nigeria's proven oil reserves is estimated to be 35 billion barrels; natural gas reserves are well over 100 trillion fti $(2,800 \mathrm{kmi})$. These quantities of petroleum is high and well enough to sustain some countries. Still sadly, vandalism as a result of poor incorporation of community members, severe environmental and ecological disasters, security challenges and greediness of the active youths and top leaders have cut through the Niger Delta oil which plagues into the oil sector(Bovas, 2018). Despite all these, there's no government program guiding the citizens or sensitizing them on how to limit these disasters, the major multinational oil companies have launched their community development programs. One of these new entities include, the Niger Delta Development Commission (NDDC). This was created to catalyze and sensitize the social development in the region Even though it has not fully launched all its programs; It has created help to that economic and social development in the region.

\section{ili. Research Methodology}

\section{a) Study Area}

The study area is Nigeria, and it stretches through $923,769 \mathrm{Km}^{-a}$ range of which 13,000 square kilometers is covered by water across 36 states from north to south. With a population of 187 million in 2017, the nation has substantial resources including crude oil. In Nigeria, states which are the largest oilproducing states and make up the 9 Federating States in the Niger Delta Region of Nigeria are, Cross River, Abia, Akwa Ibom, Ondo, Rivers, Delta, Bayelsa, Imo and Edo States.

\section{b) Data source}

This study used both primary and secondary data. The primary data from a collection of data with well-structured questionnaires and employed the use of Structural Equation Model (SEM) for analyzing the proposed objectives. The well-structured questionnaires were shared among the respondents and they were administered to them in the study area with adequate explanation and guide for putting them to the right response from their perspective. The respondents were given enough time to see to the different sets of questions relating to causes of pipeline disasters and its reaction on the environmental issues, their awareness about the effects, and their consent level about the significance of environment using the Likert-scale options. The total respondents did not fully capture all questionnaires, but the returned ones consist of 196 males and 90 females. The socioeconomic characteristics of the respondents such as age as follows: $33.6 \%$ fall within the age group of 20 $30,36.4 \%$ made up characters between the age group of $31-40$, while $10.1 \%$ is made up of the age group of $41-50$ and $5.2 \%$ is made of up the ages of 50 and above. Age is necessary to this study because the focus is on young and sharp minds of the communities affected by pipeline disasters.

\section{c) Normality assessment}

The normality assessment is not compulsory for justifying this research; it becomes necessary before undertaking SEM analysis. Although, there are a rising interest of different consent between scholars on the cut off points for skewness and kurtosis. Some researchers opined that there should be a normal distribution with the two signs basis of positive and negative sign. (DeCarlo, 1997; Kline, 2011). Factually, no agreement has been reached on the normality assessment (Kline, 2011). For this study, absolute kurtosis values ranging from \pm 2.0 to \pm 7.0 and higher have been proposed as possible early departure points of non-normality (Byrne, 2013 citing Boomsma \& Hoogland, 2001; DeCarlo, 1997; West, Finch, \& Curran, 1995). 


\section{d) Formulation of the Confirmatory Factor Analysis Model}

The Confirmatory Factor Analysis (CFA) is an alignment of EFA, and CFA is theory-driven which tries to test specific hypotheses or theories about the dimensional structure that underlines some set of variables. This analytical tool is regarded as a superior model of analysis because its purpose is to establish a figurable relationship between observed and unobserved variables. Amos graphics version 22 was used in analysing of the study. The CFA postulate and analysis research works based on the relationship between variables and indicators. This makes a researcher put a theory to test and have access to a full observation of the latent variables (Kline, 2011; Loehlin, 2004). The model for the study, even though affirmed, was validated by other expert researchers in the field after a series of pre-tests.

\section{Data Analysis and Results PRESENTATION}

This chapter gives an analysis of data collected from the field. It also presents, interprets, and discusses the findings as contained in the study. The structured Questionnaire serves as the basis for statistical analysis in which data retrieved was analyzed using appropriate statistical tools. The descriptive analysis of the data involves the use of tables, percentages frequency, and mean. While inferential statistics were carried out using Confirmatory Factor Analysis (CFA) and regression, to understand the intermediate and remote causes of pipeline disaster in Nigeria. A study of selected areas was carried out.

\section{a) Data Analysis and Presentation}

Survey copies of questionnaires were administered directly to respondents in selected listed areas. Out of three hundred (300) questionnaires distributed and sample selected, the study was able to accomplished a ninety-five-point three percent (95.3\%) response rate, which makes the study to be more reliable and valid. Also, the whole retrieved questionnaire was deemed fit, and usage for the study. The response rate is considered adequate for the study.

\section{i. Demographic Data Analyses}

Six (6) demographic variables are included in this study. They are age, gender, marital status, education level, employment status and income level. The results in below tables and figures represent the distribution of sample individuals according to demographic variables.
Table 1: Respondents Age

\begin{tabular}{|c|c|c|}
\hline Response & Frequency & Percent \\
\hline Less than 20years & 42 & 14.7 \\
\hline 20-30years & 96 & 33.6 \\
\hline 31-40years & 104 & 36.4 \\
\hline 41-50years & 29 & 10.1 \\
\hline 50years and above & 15 & 5.2 \\
\hline Total & 286 & 100.0 \\
\hline
\end{tabular}

Source: Field Survey (2020)

Table 1 shows the age distribution of the respondents; it revealed that the mean age of the respondents is 57 years. This implies that on average, the respondent's age is 57 years. Put differently; it was observed that majority $36.4 \%$ of the respondents, $14.7 \%$ were less than 20years, 33.6\% were 20-30years, $10.1 \%$ were $41-50 y e a r s$ and only $5.2 \%$ were 50years, and above. Table 2 shows the gender of respondents. It revealed that the majority 196(68.5\%) of the respondents are male, while $90(31.5 \%)$ are female.

Table 2: Gender

\begin{tabular}{|c|c|c|}
\hline Response & Frequency & Percent \\
\hline Male & 196 & 68.5 \\
\hline Female & 90 & 31.5 \\
\hline Total & $\mathbf{2 8 6}$ & 100.0 \\
\hline
\end{tabular}

Source: Field Survey (2020)

Table 3: Marital Status

\begin{tabular}{|c|c|c|}
\hline Response & Frequency & Percent \\
\hline Single & 88 & 30.8 \\
\hline Married & 102 & 35.7 \\
\hline Divorced & 32 & 11.2 \\
\hline Widow & 34 & 11.9 \\
\hline Separated & 30 & 10.5 \\
\hline Total & 286 & 100.0 \\
\hline
\end{tabular}

Source: Field Survey (2020)

Table 3 shows the gender of respondents. It revealed that the majority $(35.7 \%)$ of the respondents are married, follow by $30.8 \%$ who showed they are single. Further, $11.2 \%$ revealed they are divorce, and $10.5 \%$ are separated.

Table 4: Employment Status

\begin{tabular}{|c|c|c|}
\hline Response & Frequency & $\%$ \\
\hline Unemployed & 106 & 37.1 \\
\hline Employed & 180 & 62.9 \\
\hline Total & 286 & 100.0 \\
\hline
\end{tabular}

Source: Field Survey (2020) 
Table 4 shows the employment status of respondents. It revealed that the majority $180(62.9 \%)$ of the respondents are employed while 106(37.1\%) are unemployed.

Table 5: Education Level

\begin{tabular}{|c|c|c|}
\hline Response & Frequency & Percent \\
\hline No formal Education & 56 & 19.6 \\
\hline Primary & 81 & 28.3 \\
\hline Secondary & 77 & 26.9 \\
\hline Tertiary & 72 & 25.2 \\
\hline Total & 286 & 100.0 \\
\hline
\end{tabular}

Source: Field Survey (2020)

Table 5 shows the education level of respondents. It revealed that the majority $(28.3 \%)$ of the respondents had attained primary school certificate, $19.6 \%$ had no formal education, $26.9 \%$ had attained secondary school certificate, and $25.2 \%$ had attained tertiary school certificate. This result implies that the majority of the respondents had a formal education certificate.

\section{Table 6: Income Level}

\begin{tabular}{|c|c|c|}
\hline Response & Frequency & Percent \\
\hline Less than 200k & 90 & 31.5 \\
\hline 200k - 399k & 82 & 28.7 \\
\hline $400 \mathrm{k}$ - 699k & 40 & 14.0 \\
\hline $700 \mathrm{k}-999 \mathrm{~K}$ & 42 & 14.7 \\
\hline 1m and above & 32 & 11.2 \\
\hline Total & $\mathbf{2 8 6}$ & 100.0 \\
\hline
\end{tabular}

Source: Field Survey (2020)

Table 6 shows the income level of the respondents. It revealed that the majority $(31.5 \%)$ of the respondents earned between less than N200K annually, 28.7\% earned between N200K - N399K, 14\% earned between N400k - 699k annually, 14.7\% earned between N700K - N999K. And lastly, 11.2\% of the respondent earned $1 \mathrm{~m}$ and above.

b) Reliability

Hair et al. (2010), state that reliability is a measure of the degree to which a set of indicators of a latent construct is internally consistent in its measurement based on the degree to which the indicators are interrelated. Cronbach's Alpha is normally used to measure this internal consistency or reliability ( $A$ scale is considered reliable when Cronbach's alpha is greater than 0.7.).

\section{i. Cronbach's Alpha Reliability}

Cronbach's Alpha for each variable was calculated to reach the threshold. Causes of pipeline disaster produced a Cronbach's Alpha value of 0.983, and there were no lower values for the individual item correlations. This showed that the scale was acceptable for further multivariate analysis. Risk perception of pipeline disaster was considered nex, and this produced the highest Cronbach's Alpha value of 0.985 . It was therefore proven that all four scales were sufficiently reliable for further analysis. Lastly, the preparedness of pipeline disaster produced a Cronbach's Alpha value of 0.983, and there were no lower values for the individual item correlations (see table 7 below). 
Table 7: Cronbach's alpha reliability of latent variables

\begin{tabular}{|c|c|c|c|c|}
\hline & Items & $\begin{array}{l}\text { Corrected } \\
\text { Item-Total } \\
\text { Correlation }\end{array}$ & $\begin{array}{l}\text { Cronbach's } \\
\text { Alpha if } \\
\text { Item Deleted }\end{array}$ & $\begin{array}{l}\text { Cronbach's } \\
\text { Alpha }\end{array}$ \\
\hline \multirow{6}{*}{$\begin{array}{l}\text { Causes of } \\
\text { Pipeline disaster }\end{array}$} & Poor management of pipes, joints and valves & .939 & .982 & \\
\hline & Pipeline vandalisation & .978 & .976 & \\
\hline & Black Market & .944 & .980 & .983 \\
\hline & poverty & .919 & .982 & \\
\hline & Weak political factors & .949 & .979 & \\
\hline & Unemployment & .957 & .978 & \\
\hline \multirow[t]{5}{*}{$\begin{array}{l}\text { Preparedness of } \\
\text { pipeline } \\
\text { disaster }\end{array}$} & $\begin{array}{l}\text { I have considered the risk of pipeline the } \\
\text { explosion when deciding to live in the } \\
\text { house I do now }\end{array}$ & .954 & .975 & \\
\hline & I have obtained a working fire extinguisher & .973 & .972 & \\
\hline & $\begin{array}{l}\text { I have arranged a place to meet with family or } \\
\text { friends in case of pipeline explosion }\end{array}$ & .965 & .973 & .981 \\
\hline & $\begin{array}{l}\text { I have attended a meeting on how to better } \\
\text { prepare for the pipeline explosion }\end{array}$ & .881 & .986 & \\
\hline & I have purchased first aid kit & .954 & .975 & \\
\hline \multirow[t]{5}{*}{ Risk perception } & $\begin{array}{l}\text { How often do you think about preparing for } \\
\text { the possibility of a pipeline disaster }\end{array}$ & .966 & .981 & \\
\hline & $\begin{array}{l}\text { How often do you think about the threat of } \\
\text { pipeline disaster }\end{array}$ & .942 & .984 & \\
\hline & $\begin{array}{l}\text { How often do you think about the potential of } \\
\text { a pipeline disaster }\end{array}$ & .957 & .982 & .985 \\
\hline & $\begin{array}{l}\text { How much do you care about pipeline } \\
\text { disaster }\end{array}$ & .953 & .982 & \\
\hline & $\begin{array}{l}\text { How aware do you think the public is } \\
\text { concerning the issue of a pipeline disaster }\end{array}$ & .972 & .979 & \\
\hline
\end{tabular}

Source: Field Survey (2020)

c) Analysis Based on latent variables

The weightings adopted for the section are $S A=5, A=4, N=3, D=2$, and $S D=1$. Mean value $=(5$ $+4+3+2+1) / 5=15 / 3=3.00$. A cut off point of 3.0 will be adopted for decision taking. If the item mean value is equal to or greater than 3.0 the item is accepted, but if it is less than 3.0, the item is rejected

Table 8: Environment Awareness of Pipeline disaster

\begin{tabular}{|c|c|c|c|c|c|c|c|}
\hline \multicolumn{1}{|c|}{ Responses } & $\mathrm{SD}(\%)$ & $\mathrm{D}(\%)$ & $\mathrm{N}(\%)$ & $\mathrm{A}(\%)$ & $\mathrm{SA}(\%)$ & $\mathrm{MEAN}$ & Remark \\
\hline $\begin{array}{l}\text { Environment Awareness } \\
\text { of Pipeline disaster }\end{array}$ & $42(14.7)$ & $16(5.6)$ & $78(27.3)$ & $95(33.2)$ & $55(19.2)$ & 3.37 & AGREE \\
\hline
\end{tabular}

Source: Field Survey (2020)

As revealed in Table 8 above it was obvious that the environment is aware of pipeline disaster dues to the agreement and disagreement of respondents to the statement under construct.

\section{Table 9: Factors that causes pipeline disaster}

\begin{tabular}{|c|c|c|c|c|c|c|c|}
\hline Responses & $\mathrm{SD}(\%)$ & $\mathrm{D}(\%)$ & $\mathrm{N}(\%)$ & $\mathrm{A}(\%)$ & $\mathrm{SA}(\%)$ & MEAN & RANK \\
\hline $\begin{array}{c}\text { Poor management of pipes, } \\
\text { joints and valves }\end{array}$ & $\begin{array}{c}88 \\
(30.8)\end{array}$ & $\begin{array}{c}27 \\
(9.4)\end{array}$ & $\begin{array}{c}36 \\
(12.6)\end{array}$ & $\begin{array}{c}62 \\
(21.7)\end{array}$ & $\begin{array}{c}73 \\
(25.5)\end{array}$ & 3.02 & $6 \mathrm{TH}$ \\
\hline Pipeline vandalisation & $36(12.6)$ & $53(15.7)$ & $44(15.4)$ & $70(24.5)$ & $83(29.0)$ & 3.39 & 4TH \\
\hline Black Market & $42(14.7)$ & $16(5.6)$ & $78(27.3)$ & $95(33.2)$ & $55(19.2)$ & 3.37 & $5 T H$ \\
\hline poverty & $23(8.0)$ & $18(6.3)$ & $34(11.9)$ & $98(34.3)$ & $113(39.5)$ & 3.91 & $1 S T$ \\
\hline Weak political factors & $15(5.2)$ & $81(28.3)$ & $19(6.6)$ & $102(35.7)$ & $69(24.1)$ & 3.45 & $3 R D$ \\
\hline Unemployment & $65(22.7)$ & $38(13.3)$ & $70(24.5)$ & $93(32.5)$ & $100(35)$ & 3.61 & 2ND \\
\hline
\end{tabular}

Source: Field Survey (2020) 
As shown in table 9, the causes identified by respondents as the least causes of pipeline disaster are poor management of pipes, joint and valves, black market sale of petroleum products, and pipeline vernalization which ranked $6^{\text {th }} 5^{\text {th, }} 4^{\text {th }}$ respectively. On the other hand, we can deduce from table 9 that poverty, weak political factors, and unemployment, are the most influential causes of pipeline disaster in Nigeria.

Table 10: level of preparedness of pipeline disaster

\begin{tabular}{|l|c|c|c|c|c|c|c|}
\hline \multicolumn{1}{|c|}{ Responses } & $\mathrm{SD}(\%)$ & $\mathrm{D}(\%)$ & $\mathrm{N}(\%)$ & $\mathrm{A}(\%)$ & $\mathrm{SA}(\%)$ & MEAN & DECISION \\
\hline $\begin{array}{l}\text { I have considered the risk of } \\
\text { pipeline explosion when } \\
\text { deciding to live in the house } \\
\text { do now }\end{array}$ & $79(27.6)$ & $58(20.3)$ & $40(14.0)$ & $92(32.2)$ & $17(5.9)$ & 2.69 & DISAGREE \\
\hline $\begin{array}{l}\text { I have obtained a working fire } \\
\text { extinguisher }\end{array}$ & $89(31.1)$ & $34(11.9)$ & $70(24.5)$ & $45(15.7)$ & $48(16.8)$ & 2.75 & DISAGREE \\
\hline $\begin{array}{l}\text { I have arranged a place to } \\
\text { meet with family or friends in } \\
\begin{array}{l}\text { case of pipeline } \\
\text { explosion }\end{array}\end{array}$ & $94(32.9)$ & $72(25.2)$ & $29(10.1)$ & $58(19.9)$ & $33(11.9)$ & 2.53 & DISAGREE \\
\hline $\begin{array}{l}\text { I have attended a meeting on } \\
\text { how to better prepare for } \\
\text { pipeline explosion }\end{array}$ & $42(14.7)$ & $16(5.6)$ & $78(27.3)$ & $95(33.2)$ & $55(19.2)$ & 3.37 & AGREE \\
\hline $\begin{array}{l}\text { I have purchased a first aid kit } \\
\text { have }\end{array}$ & $102(35.7)$ & $67(23.4)$ & $39(13.6)$ & $36(12.6)$ & $42(14.7)$ & 2.47 & DISAGREE \\
\hline
\end{tabular}

\section{Source: Field Survey (2020)}

As showed in table 10, the variables for disaster preparedness as measured through actual preparedness behaviours such as acquiring a first-aid kit, having a family evacuation plan, attending meetings of how to better prepared and purchase of fire extinguisher. This is driven mainly by the need to increase preparedness at the individual level. As indicated by Miller, Adame, and (2013): "Some large amount of the respondents revealed they are unprepared for pipeline disaster; due to their response towards preparedness for pipeline disaster. For instance, the majority $58.4 \%$ and $67.5 \%$ disagree and strongly disagree to the arrangement of a place to meet with family or friends in case of a pipeline explosion and obtaining a working fire extinguisher, respectively.

\section{Table 11: Risk perception of individual on pipeline disaster}

\begin{tabular}{|l|c|c|c|c|c|}
\hline \multicolumn{1}{|c|}{ Responses } & $\mathrm{N}(\%)$ & $\mathrm{NO}(\%)$ & $\mathrm{S}(\%)$ & VO (\%) & $\mathrm{A} \mathrm{( \% )}$ \\
\hline $\begin{array}{l}\text { How often do you think about preparing for the possibility of pipeline } \\
\text { disaster }\end{array}$ & $34(11.9)$ & $56(19.6)$ & $67(23.4)$ & $76(26.6)$ & $53(15.7)$ \\
\hline How often do you think about the threat of pipeline disaster & $42(14.7)$ & $16(5.6)$ & $78(27.3)$ & $95(33.2)$ & $55(19.2)$ \\
\hline How often do you think about the potential of pipeline disaster & $67(23.4)$ & $51(17.8)$ & $13(4.5)$ & $112(39.2)$ & $43(15.0)$ \\
\hline How much do you care about pipeline disaster & $89(31.1)$ & $34(11.9)$ & $70(24.5)$ & $45(15.7)$ & $48(16.8)$ \\
\hline $\begin{array}{l}\text { How often do you think the public is concerning the issue of pipeline } \\
\text { disaster }\end{array}$ & $36(12.6)$ & $53(15.7)$ & $44(15.4)$ & $70(24.5)$ & $83(29.0)$ \\
\hline
\end{tabular}

Source: Field Survey (2020)

Note: $\mathrm{N}=$ Never, $\mathrm{NO}=$ Not Often, $\mathrm{S}=$ Sometimes, $\mathrm{VO}=$ Very Often, $\mathrm{A}=$ Always

As showed in table 11, it was obvious that most of the respondents perceived more risk of pipeline disaster, this was observed due to reaction of the respondents to the questions under risk perception. For instance, about $53.5 \%$ of the respondent very often and always think the public is concerning the issue of pipeline disaster. 


\section{d) Test of Normality}

It is important to check the normality of data before embarking on Confirmatory Factor Analysis. The skewness and Kurtosis were adopted in this study to examine the normality of the data collected through the filed survey. It has been observed that there is a lack of consensus among scholars and in different kinds of literature on the cut-off points for determining normality of data using skewness and kurtosis with a base of the positive and negative sign of kurtosis and the skewness (DeCarlo, 1997; Kline, 2011). However, some scholars agree on absolutes kurtosis values ranging from \pm 2.0 to \pm 7.0 and higher to be a sign of non-normality of data set (see Byrne, 2013; Decarlo, 1997; West, Finch, \& Curran 1995). The normality test of the data for this study is presented in table 12 -:

Table 12: Normality Test

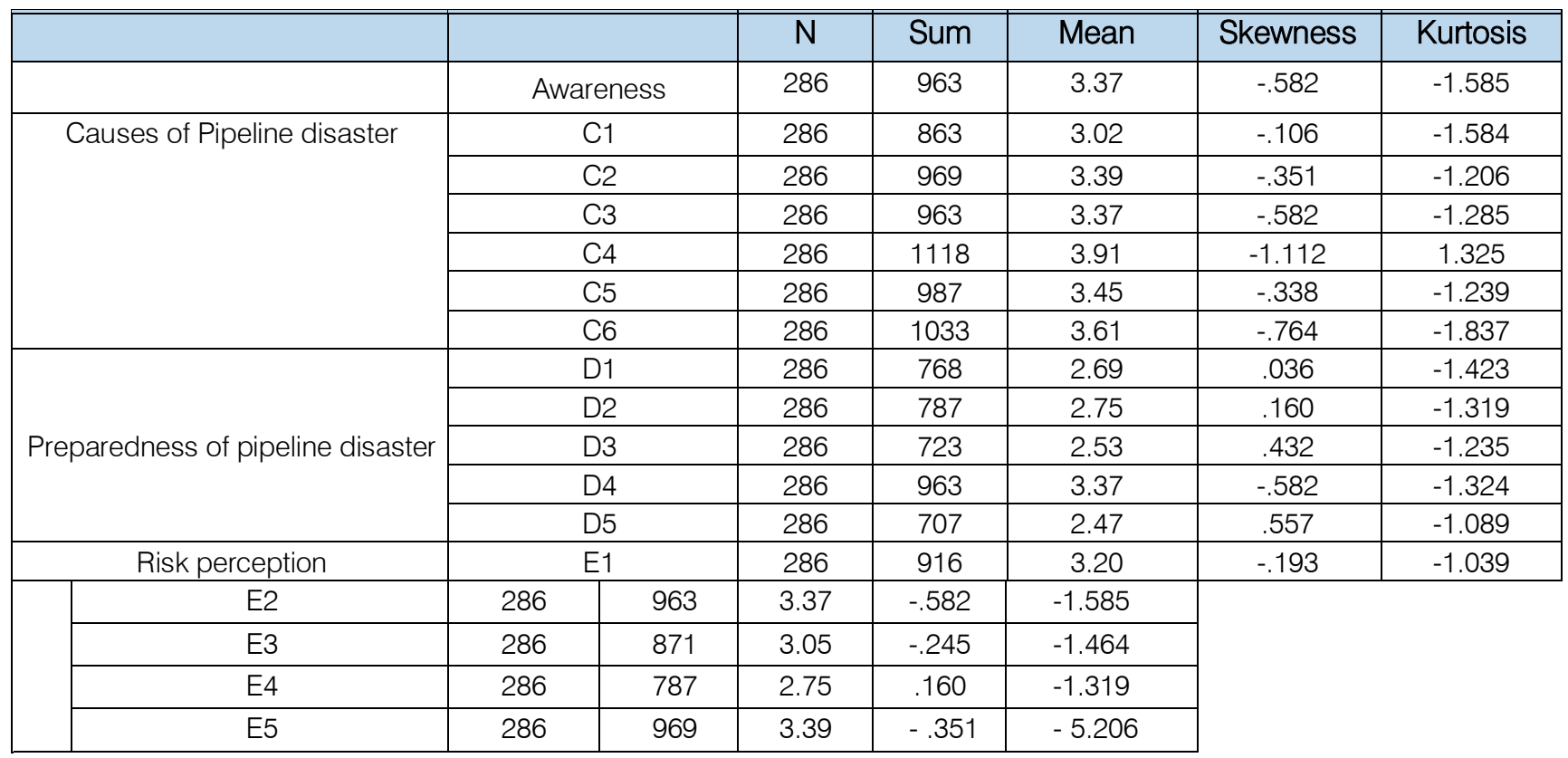

Source: Field Survey (2020) SPSS 25.0

As shown in Table 12 above, following the study of Byrne (2013) by using kurtosis within the range of \pm 2.0 and \pm 7.0 . The skewness of the data for this study falls within -1.112 to -.160 , while kurtosis 1.194 to -5.206 , which is still within the acceptable limit. From the questionnaire the respondents were asked set of questions relating to causes of pipeline disaster, risk perception of pipeline disaster, awareness about pipeline disaster and level of preparedness of pipeline disaster as indicated in the questionnaire from the Likert-scale options 1-5: Strongly Disagree $=1$; Disagree $=2$; Disagree $=3$; Agree $=4$ and Strongly
Agree $=5$. As well as $1=$ Never, $2=$ Not Often, $3=$ Sometimes, $4=$ Very Often, $5=$

Always

e) Confirmatory Factor Analysis (CFA)

Confirmatory Factor Analysis (CFA) was adopted in this study to provide analysis of the relationship between the key variables (such as demographic characteristics, risk perspective, and preparedness of pipeline disaster) and their corresponding indicators.

Table 13: Model Fit Evaluation of the Confirmatory Factor Analysis

\begin{tabular}{|c|c|c|}
\hline Metric/Statistic & Observed Value & Recommended value \\
\hline CMIN/df & 3.904 & between 1 and 3 \\
\hline CFI & 1.000 & $>0.950$ \\
\hline RMSEA & 0.042 & $<0.060$ \\
\hline CLOSE & 0.904 & $>0.050$ \\
\hline
\end{tabular}

Source: Field Survey (2020) AMOS 24.0

As showed in table 13 above, it was observed that the fitted CFA model showed goodness-of-fit to the data. All the factors showed high loading values, and thus, none of the factors were removed. The model fit 
indices showed values which are above the threshold and was reported as such. Table 4 below shows that the goodness of fit for the measurement model is sufficient (see appendix.)

\section{f) Structural Model}

Composite variables were created using factors from AMOS version 24. The data was imputed to derive the composite variables and they were used to create the composite model. The path diagram for the CFA was present in figure 1 below:

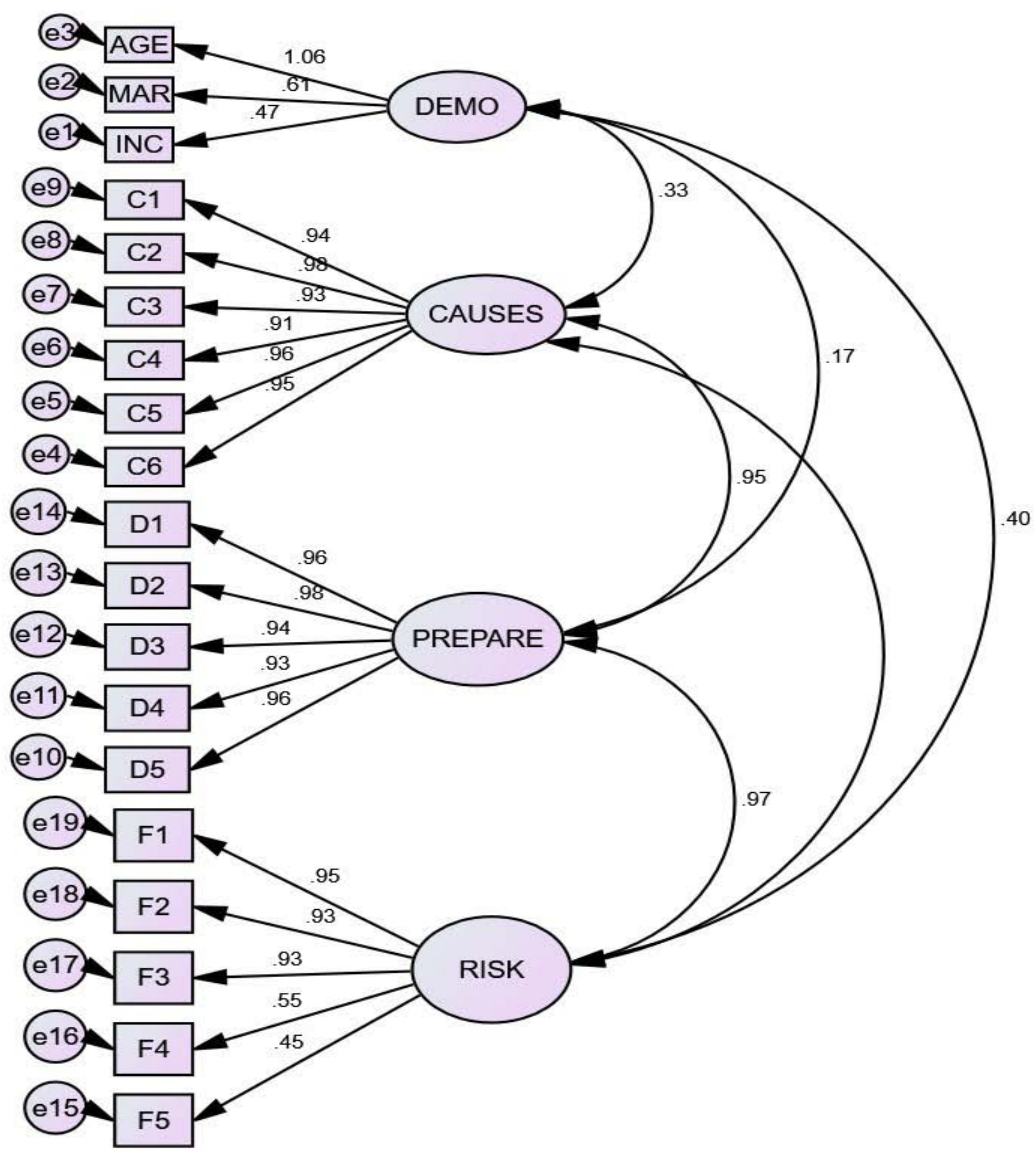

Figure 2: Confirmatory Factor Analysis (CFA)

Notes for Model (Default model)

Computation of degrees of freedom (Default model)

\begin{tabular}{|l|c|}
\hline Number of distinct sample moments: & 190 \\
\hline $\begin{array}{l}\text { Number of distinct parameters to be } \\
\text { estimated: }\end{array}$ & 44 \\
\hline Degrees of freedom (190 - 44): & 146 \\
\hline
\end{tabular}

Result (Default model)

Minimum was achieved

Chi-square $=7614.019$

Degrees of freedom $=146$

Probability level $=.000$

Note: C inputs represent causes of pipeline disaster, D inputs represent, Preparedness for pipeline disaster and F input represent risk perspective of pipeline disaster. 
Table 14: Structural Equation (Model)

\begin{tabular}{|c|c|c|c|c|c|c|}
\hline & & & Estimate & S.E. & C.R. & P \\
\hline Pipeline Disaster & $<---$ & Demo & 0.923 & 0.019 & 48.018 & ${ }^{\star \star *}$ \\
\hline Pipeline Disaster & $<---$ & Causes & 0.844 & 0.022 & 38.951 & ${ }^{\star \star \star}$ \\
\hline Pipeline Disaster & $<---$ & Prepared & 0.887 & 0.022 & 41.19 & $* \star \star$ \\
\hline Pipeline Disaster & $<---$ & Risk & 1.023 & 0.018 & 57.224 & $\star \star \star$ \\
\hline
\end{tabular}

Source: Field Survey (2020) AMOS 24.0

Note: ${ }^{* * *}$ indicate variable significance at $1 \%$

From the model in table 14 above, the results generated indicated that demographic factors (such as age, marital status, and income level) significantly contribute to pipeline disaster in Nigeria (Coefficient = $0.923, C R=48.018 \& P$ value $=0.000$ ). The study also revealed that factors such as poverty, poor management of pipelines, political factor and all other factors treated in the study contribute to pipeline disaster in Nigeria. Further, it was also observed that preparedness and risk perceptive factors also contribute to the pipeline disaster in Nigeria.

\section{Conclusion and Recommendations}

Base on the findings of the research, the demographic details of the respondents, shows they are majorly active youths (gender; male and age; 31-40 years), with the majority of them having primary school certificates. The researchers conclude that poverty, weak political factors, and unemployment, are the most influential causes of pipeline disaster in Nigeria, while some of the least significant factors are; poor management of pipes, joint and valves, black market sale of petroleum products, and pipeline vandalization. It was also affirmed that a large percentage of the respondents are unprepared for the disasters to the fact that, the majority disagree and strongly disagree to the arrangement of a place to meet with family or friends in case of a pipeline explosion and obtaining a working fire extinguisher respectively. The researchers also conclude that increase in the creation of wealth by providing employment opportunities and also social amenities in the form of infrastructure such as good roads, health facilities, stable electric supply, pipe-borne water and reduction in land degradation will bring an end to vandalism of pipelines thereby reducing the disasters level and sustain lasting peace within the society.

Furthermore, the researchers also recommend that:

(i) Technical know-how with the pipeline should be handled by experts and the coatings of the outside should be tackled by improved Coatings such as the use or polyethylene at multiple layers for longer life. The degradation on any of the pipelines should be regularly checked, and as soon as it is detected of leaks should be a tester with hydrostatic testing. (ii) Internal corrosion should also be prevented by dehydration of gases and periodic pigging of lines to remove accumulated deposits or water.

\section{References Références Referencias}

1. Acemoglu, D., Johnson, S., Robinson, J., \& Thaicharoen, Y. (2003). Institutional causes, macroeconomic symptoms: Volatility, crises and growth. Journal of Monetary Economics, 50,49-123. https://doi.org/10.1016/S0304-3932(02)00208-8

2. Akpomera, E. (2015). International crude oil theft: Elite predatory tendencies in Nigeria. Review of African Political Economy, 42, 156-165. https://doi.org/10.1080/03056244.2014.988696

3. Agbaeze, K. N., (2000); Petroleum Pipe Leakages PPMC Report for Chief Officiers Mandatory Course 026, Lagos.

4. Al-Kasim, F., Søreide, T., \& Williams, A. (2013). Corruption and reduced oil production: An additional resource curse factor? Energy Policy, 54, 137-147. https://doi.org/10.1016/j.enpol.2012. 11.007. Ambituuni, A., Amezaga, J., \& Emeseh, E. (2014). Analysis of safety and environmental regulations for downstream petroleum industry operations in Nigeria: Problems and prospects. Environmental Development, 9, 43-60.

5. Awobanjo, S.A., (1981); Oil spillage in Nigeria: 1976 - 1980, Paper presented at the 1981 International Seminar on the Oil Industry, NNPC, Lagos. Bräutigam, D. A., \& Knack, S. (2004). Foreign aid, institutions, and governance in Sub-Saharan Africa. Economic Development and Cultural Change, 52, 255-285.https://doi.org/10.1086/380592. • Byrne, B. M. (2013). Structural equation modeling with Mplus: Basic concepts, applications, and programming. New York, NY: Routledge.

6. Bovas Journals, (2018). The impact of environmental management on firm performance; 11: 2-3.

7. Chen, Xiao and Chun-Chieh C. Growth with pollution: unsustainable development in Taiwan and its consequences. Stud Compar Int Dev 2008;29(2): 23-47.

8. d'Agostino, G., Dunne, J. P., \& Pieroni, L. (2016). Government spending, corruption and economic 
growth. World Development, 84, 190-205. https://doi.org/10.1016/j.worlddev.2016.03.011.

9. Eze G. (2006). Environmental cost and responsibilities resulting from oil exploitation in developing countries: The case of the Niger Delta of Nigeria. Jo

10. Friedmann J. Urbanization. Planning and national development. Los Angeles: Sage; 1973.

11. NNPC. (2013). NNPC annual statistical bulletin (First edition). Corporate Planning and Strategy Division. Retrieved from www.nnpcgroup.com

12. Moffat, Daniel and Linden, Olofu, (2005); Perception and reality: Assessing priorities for sustainable development in the Niger Delta, AMBIO: Journal of Human Environment, Vol. 24, and Nos. 7-8, pp.527-538.

13. Nwankwo, D. I., Chukwu, L. O., and Brown, C. O., (1998); The impact of oil pollution on the hydrochemistry and biota of the tidal creeks and canals in Ondo State, 9th International Conference on the Petroleum Industry and the Nigerian Environment,

14. Abuja, pp.538-576 - Imevbore AMA, Odu CA. Environmental pollution in the Niger Delta.In: Wilcox, BHR, Powel, CB (Eds.) Proceedings of a workshop on the mangrove ecosystem of the Niger Delta university of Port-Harcourt, Nigeria; 19-23 May 1985, pp. 133-55.

15. Incardona JP, Collier TK, Scholz NK. Oil spills and fish health: exposing the heart of the matter. J. Expo Sci Environ Epidemiol 2010;. http://dx.doi.org/ 10.1038/jes.2010.51.

16. Isichei $A O$, Ero $H$. Responses of savanna to stress and disturbance the beginning of desertification. In: Sagua, VO, Enabor, EE Kio, PRO, 2017.

17. Jike VT. Environmental degradation, social disequilibrium, and the dilemma of sustainable development in the Niger-Delta of Nigeria. J Black Stud 2004;34(5):686-701.

18. Karl TL. The paradox of plenty: oil booms and petrostates. USA: University of California Press; 1997 (342p.). - Ojanuga, AU, Mortimore, M, Kalu, AE (Eds.) Ecological disasters in Nigeria: drought desertification, Lagos, Nigeria; 1987, pp. 78-92.

Omotola, J. S. (2009). "Liberation movements" and rising violence in the Niger Delta: The new contentious site of oil and environmental politics. Studies in Conflict \& Terrorism, 33, 36-54. https://doi.org/10.1080/10576100903400597.

19. Ulman, S. R., \& Bujancă, G. V. (2014). The corruption influence on the macroeconomic environment. Empirical analysis on countries development stages. Procedia Economics and Finance, 16, 427-437•UNEP. (2011). Environmental assessment of Ogoniland First published in 2011 by the United Nations Environment Programme. United Nations Environment Programme.
20. United Nations Development Report (UNDP). (2006). Niger Delta Development Human Report. Abuja: United Walter \& Pettigrew. 